\title{
SOFT GROUND IMPROVEMENT VIA VERTICAL DRAINS AND VACUUM ASSISTED PRELOADING
}

\section{Buddhima Indraratna*}

Professor and Head, School of Civil, Mining and Environmental Engineering, Director, Centre for Geomechanics and Railway Engineering; University of Wollongong, Wollongong City, NSW 2522, Australia

\section{Cholachat Rujikiatkamjorn}

Senior Lecturer, School of Civil, Mining and Environmental Engineering, University of Wollongong, NSW 2522, Australia

\section{A. S. (Bala) Balasubramaniam}

Professor of Geotechnical Engineering, Griffith University, Gold Coast, Queensland, Australia

\section{Geoffrey McIntosh}

Principal, Douglas Partners Pty Ltd, Unanderra, NSW Australia

Submitted to: Geotextiles and Geomembranes

*Author for correspondence:

Prof. B. Indraratna

Faculty of Engineering

University of Wollongong

Wollongong, NSW 2522

Australia.

Ph: +61242213046

Fax: +61242213238 


\title{
SOFT GROUND IMPROVEMENT VIA VERTICAL DRAINS AND VACUUM
}

ASSISTED PRELOADING

\section{Buddhima Indraratna, Cholachat Rujikiatkamjorn, A. S. (Bala) Balasubramaniam, and Geoffrey McIntosh}

\begin{abstract}
Application of vacuum assisted preloading is an imperative method when a considerable load is required to meet the desired rate of settlement and an increase in the undrained shear strength upon consolidation. Moreover, where lateral displacements at the edge of a coastal embankment need to be controlled, application of vacuum pressure with a cut off offers the optimum solution. To facilitate vacuum propagation, vertical drains are usually employed in conjunction. The installation of vertical drains using a steel mandrel creates significant remoulding of the subsoil surrounding the drains thereby, reducing soil permeability and adversely affecting the soil consolidation process. In this paper, the simulation of vacuum assisted consolidation using the spectral method and finite element analysis is carried out. Subsequently, the 2D and 3D numerical multi-drain analyses are conducted to predict the excess pore pressures, lateral and vertical displacements. The performance of two selected case histories at the sites of Suvarnabhumi Airport, Thailand and Tianjin Port, China are discussed and analysed. The numerical predictions are then compared with the available field data. Finally, a procedure for the design of vertical drains is presented with a worked-out example.
\end{abstract}

Keywords: Case histories, Numerical analysis, Vacuum consolidation Vertical drains, 


\section{INTRODUCTION}

Soft clay deposits possess a low bearing capacity and high compressibility characteristics. Therefore, it is imperative to apply ground improvement techniques to the existing soft soils prior to construction, in order to prevent unacceptable differential settlement. The application of prefabricated vertical drains (PVDs) and preloading (surcharge and vacuum load) has become one of the most viable soil improvement techniques. Vertical drains provide considerably shortened horizontal drainage paths for pore water flow, thereby accelerating the soil consolidation (Hansbo, 1981; Indraratna and Redana, 2000; Bergado et al. 2002; Chai et al. 2010). In order to control the risk of embankment failure, surcharge embankments with vacuum application are usually employed to accelerate the rate of settlement without increasing the excess pore pressure (Qian et al., 1992; Shang et al., 1998; Chu et al. 2000, Saowapakpiboon et al. 2010). This practice has been employed for land reclamation and port projects as a high surcharge embankment over the soft dredged fills cannot be raised due to various stability issues (Chu and Yan, 2005). The PVD system facilitates the vacuum pressure distribution to deep subsoil layers in the absence of the surcharge load influence, thereby increasing the consolidation rate (Chu et al. 2006, Leong et al. 2010). The vacuum system enhances the stability of any raised embankment by minimizing the excess pore pressure at its base, and increasing the shear strength of the sand platform. Vacuum consolidation with PVDs is a sustainable option as it does not leave any chemical residue in the soil or groundwater, and has no unacceptable noise levels compared to driven piles. Moreover, vacuum consolidation is isotropic, thereby minimizing the excessive lateral displacement due to high surcharge.

In this paper, modified radial consolidation theory using the spectral method capturing the variation of soil permeability with depth is proposed. The equivalent (transformed) plane 
strain conversion employing the modified Cam-clay theory was compared with the actual three-dimensional finite element analysis. It has been shown that 2D plane strain finite element analysis is often adequate to predict settlements, pore pressures and lateral displacements if the conversion from axissymmetry to plane strain ensures the same time consolidation response. Two case histories are discussed and analysed, including the Suvarnabhumi Airport (Thailand) and Tianjin Port in China. The predictions are compared with the available field data.

\section{THEORETICAL MODELLING FOR SOFT GROUND CONSOLIDATION VIA VERTICAL DRAINS AND VACUUM PRELOADING: A SINGLE DRAIN ANALYSIS}

The vacuum consolidation theory for radial drainage with smear effect was proposed by Mohamedelhassan and Shang, (2002) and Indraratna et al. (2005a). Recently, Rujikiatkamjorn and Indraratna (2009) a proposed comprehensive solution to vacuumassisted consolidation with both vertical and horizontal drainage including the smear effect, applicable to a single layer soil. Walker and Indraratna (2009) proposed a rigorous solution via spectral method for multi-layer soil improved by vacuum and surcharge preloading via PVDs.

In a unit cell (Fig. 1), the average pore pressure $\bar{u}$ at normalized depth $Z$ is given by:

$$
\begin{aligned}
& \frac{m_{v}}{\bar{m}_{v}} \frac{\partial \bar{u}}{\partial t}=-\left[d T_{h} \frac{\eta}{\bar{\eta}} \bar{u}-d T_{v}\left(\frac{\partial}{\partial Z}\left(\frac{k_{v}}{\bar{k}_{v}}\right) \frac{\partial \bar{u}}{\partial Z}+\frac{k_{v}}{\bar{k}_{v}} \frac{\partial^{2} \bar{u}}{\partial Z^{2}}\right)\right]+f(Z, t) \\
& d T_{v}=\frac{\bar{c}_{v}}{H^{2}} \\
& d T_{h}=\frac{2 \bar{\eta}}{\gamma_{w} \bar{m}_{v}}
\end{aligned}
$$




$$
\begin{aligned}
& \bar{c}_{v}=\frac{\bar{k}_{v}}{\gamma_{w} \bar{m}_{v}} \\
& Z=\frac{Z}{H} \\
& f(Z, t)=\frac{m_{v}}{\bar{m}_{v}} \frac{\partial \bar{\sigma}}{\partial t}+d T_{h} \frac{\eta}{\bar{\eta}} w
\end{aligned}
$$

where, $r_{e}=$ drain influence radius, $\gamma_{w}=$ unit weight of water, $\mu=$ dimensionless parameter influenced by smear zone, $k_{h}=$ horizontal soil permeability $\bar{k}_{v}=$ initial vertical soil permeability, $H=$ soil thickness, $k_{v}=$ horizontal soil permeability, $\bar{m}_{v}=$ initial coefficient soil volume compressibility, $m_{v}=$ coefficient soil volume compressibility, $\bar{\sigma}=$ average total stress, $t=$ time, $w=$ pore pressure at the soil drain boundary.

For constant permeability in the smear zone (Fig. 2a) the value of $\mu$ can be determined from (Hansbo 1981):

$$
\mu=\ln (n / s)+(\kappa) \ln (s)-0.75
$$

For linear variation of permeability in the smear zone (Fig. 2b), $\mu$ can be determined from (Walker and Indraratna 2006):

$$
\mu_{L}=\ln \left(\frac{n}{s}\right)-\frac{3}{4}+\frac{\kappa(s-1)}{s-\kappa} \ln \left(\frac{s}{\kappa}\right)
$$

For parabolically varying smear zone (Fig. 2c), the $\mu$ parameter can be determined from (Walker and Indraratna 2007): 


$$
\mu=\ln \left(\frac{n}{s}\right)-\frac{3}{4}+\frac{\kappa(s-1)^{2}}{\left(s^{2}-2 \kappa s+\kappa\right)} \ln \left(\frac{s}{\sqrt{\kappa}}\right)-\frac{s(s-1) \sqrt{\kappa(\kappa-1)}}{2\left(s^{2}-2 \kappa s+\kappa\right)} \ln \left(\frac{\sqrt{\kappa}+\sqrt{\kappa-1}}{\sqrt{\kappa}-\sqrt{\kappa-1}}\right)
$$

where, $n=r_{e} / r_{w}$ and $s=r_{s} / r_{w}$, and $\kappa$ is the ratio of undisturbed horizontal permeability to smear zone permeability at the drain/soil interface.

The average excess pore pressure at depth $Z$, time $t$, can be expressed by:

$$
\bar{u}(Z, t)=\int_{0}^{\tau} \int_{0}^{1} \bar{u}_{\delta}(Z, t, \zeta, \tau) f(Z, t) d \zeta d \tau
$$

Based on the spectral method, Eq. 10 can be expressed in matrix form as:

$$
\bar{u}(Z, t) \approx \boldsymbol{\Phi v E}(\boldsymbol{\Gamma} \mathbf{v})^{-1}\left[\begin{array}{llll}
\theta_{1} & \theta_{2} & \ldots & \theta_{N}
\end{array}\right]^{T}
$$

The diagonal matrix $\mathbf{E}$ can be represented by:

$$
\mathbf{E}(t)=\operatorname{diag}\left[\exp \left(-\lambda_{1} t\right) \quad \exp \left(-\lambda_{2} t\right) \quad \cdots \quad \exp \left(-\lambda_{N} t\right)\right]
$$

where, $\lambda$ is an Eigen value of matrix $\boldsymbol{\Gamma}^{-1} \boldsymbol{\Psi}$. The eigenvector associated with each Eigen value makes up the columns matrix $\mathbf{v}$ (i.e. $v_{i 1}$ is the eigenvector associated with $\lambda_{1}$ ). $\boldsymbol{\theta}$ is a column vector defined by:

$$
\theta_{i}=2\left(1-\cos \left(M_{i}\right)\right) / M_{i}
$$

To determine the average pore pressure between depth $Z_{1}$ and $Z_{2}$ the $\phi_{j}(z)$ terms in $\boldsymbol{\Phi}$ are replaced with:

$$
\bar{\phi}_{j}\left(Z_{1}, Z_{2}\right)=\left(\cos \left(M_{j} Z_{1}\right)-\cos \left(M_{j} Z_{2}\right)\right) / M_{j}\left(Z_{2}-Z_{1}\right)
$$

The above method is straight forward in determining the average pore pressure values within a soil layer, across some layers, or across all layers. The spectral method is a meshless 
approach producing a series solution to the consolidation problem based on matrix operations. Equation (11) shows that the soil consolidation can be reduced to a series of matrix operations.

\section{Application to a case history}

The Suvarnabhumi Airport is located about 30km east of Bangkok, Thailand. At this site, soft estuarine clay deposits often present considerable construction problems because of low bearing capacity and high compressibility (Seah 2006). Appropriate ground improvement techniques to prevent excessive settlement and lateral movement are required prior to commencement of the construction of permanent structures. In the past, the site was used mainly for aqua-cultural and agricultural activities. The area is often flooded during the wet season and therefore the moisture content of soil is generally very high throughout the year.

The subsoil profile can be divided into five distinctive layers. A weathered crust of approximately $2 \mathrm{~m}$ thickness (highly overconsolidated clay) overlies a very soft to medium clay, which extends beyond 10m below the ground surface. Beneath the medium clay layer, a light-brown stiff clay layer is found within a depth range depth of $10-21 \mathrm{~m}$. The ground-water level varies between 0.5 and $1.5 \mathrm{~m}$ below the surface. The typical soil profile and its properties are illustrated in Fig. 3. The moisture content of the very soft clay layer changes from 75 to $105 \%$, while in the lower parts of the layer (10-14m) it varies from 45 to $75 \%$. The plastic limit and liquid limit of the upper and lower layers are comparable, in the range of 85 to $105 \%$ and 15 to $45 \%$, respectively (Fig. 3).

As reported by Bergado et al. (1998), at this site, two embankments were built with PVDs $(100 \mathrm{~mm} \times 3 \mathrm{~mm})$ installed at $1 \mathrm{~m}$ spacing in a triangular pattern. PVDs of $15 \mathrm{~m}$ in length were installed under the Embankment TV1, and 12m long PVDs were installed beneath the Embankment TV2. Soil parameters are tabulated in Table 1. A $60 \mathrm{kPa}$ suction 
pressure was applied and the embankment height was subsequently raised to a height of $2.5 \mathrm{~m}$ $\left(\gamma=18 \mathrm{kN} / \mathrm{m}^{3}\right)$. The calculated and measured surface settlements for the two embankments based on the spectral analysis, along with the surcharge and assumed vacuum loading stages, are illustrated in Fig. 4. Loss of vacuum may be attributed to air leaks along drain length and surface. The calculated surface settlements agree well with the measured values verifying the capability of the proposed model to analyse multi-layer problems with different loading stages.

\section{THEORETICAL MODELLING FOR SOFT GROUND CONSOLIDATION VIA VERTICAL DRAINS AND VACUUM PRELOADING: MULTI-DRAIN ANALYSIS}

A unit cell theory for vacuum consolidation including a single drain assuming equal strain was proposed by Indraratna et al. (2005a). The obvious constraint of this single drain analysis is that it cannot successfully predict the overall consolidation in a large project where an array of drains is installed. Essentially, a single drain analysis can only be applicable at the embankment centerline where the lateral displacements are negligible. Towards the embankment toe, the analysis using a single drain approach can be quite inaccurate mainly due to the non-equal surcharge load distribution, large lateral strain conditions, effects of embankment geometry and heave at the embankment toe (Indraratna and Redana, 1997 Indraratna et al., 2005a).

To analyse the multi-drain problem using a plane strain finite element analysis, the appropriate equivalence conversion must be established to obtain the same time-settlement curves. Hird et al. (1992) proposed an equivalent plane strain technique, which can be used in numerical modeling. Realistic field predictions require the in-situ properties to be converted to equivalent 2D plane strain properties, especially with regard to the permeability 
coefficients, vacuum pressure and drain geometry (Indraratna et al. 2005, Tran and Mitachi 2006). Chai et al. (2001) proposed an approximate method for analyzing PVD improved subsoils, whereby an equivalent vertical hydraulic conductivity was derived to conveniently combine the effect of vertical and horizontal hydraulic conductivities of the natural subsoil. However, this technique cannot be used to simulate the propagation of vacuum pressure. The permeability conversion for equivalent plane strain condition has been considered as a simple but accurate approach as the drain and smear zone geometry remains the same. Below is a summary of the conversion from the true axisymmetric condition to the equivalent plane strain model by Indraratna et al. (2005a).

The corresponding ratio of the smear zone permeability to the undisturbed zone permeability in plane strain analysis $\left(\frac{k_{s, p s}}{k_{h, p s}}\right)$ can be obtained by:

$$
\begin{aligned}
& \frac{k_{s, p s}}{k_{h, p s}}=\frac{\beta}{\frac{k_{h, p s}}{k_{h, a x}}\left[\ln \left(\frac{n}{s}\right)+\frac{k_{h, a x}}{k_{s, a x}} \ln (s)-\frac{3}{4}\right]-\alpha} \\
& \beta=\frac{2(s-1)}{n^{2}(n-1)}\left[n(n-s-1)+\frac{1}{3}\left(s^{2}+s+1\right)\right] \\
& \alpha=\frac{2}{3} \frac{(n-s)^{3}}{n^{2}(n-1)} \\
& s=d_{s} / d_{w} \\
& n=d_{e} / d_{w}
\end{aligned}
$$

where, $k_{s, a x}$ and $k_{h, a x}=$ lateral soil permeability in the smear zone and in the undisturbed zone, respectively, in the axisymmetric condition. $d_{e}=$ the diameter of soil influence zone, $d_{s}=$ the smear zone diameter, $d_{w}=$ the equivalent PVDs diameter. 
The undisturbed lateral permeability ratio of equivalent plane strain to axisymmetric permeability can be determined by:

$$
\frac{k_{h, p s}}{k_{h, a x}}=\frac{0.67(n-1)^{2} / n^{2}}{[\ln (n)-0.75]}
$$

An equivalent vacuum pressure can now be expressed by:

$$
p_{0, p s}=p_{0, a x}
$$

\section{Case Study of Tianjin Ports: Site descriptions, soil parameters and embankment characteristics}

Due to the rapid development of the Tianjin Port, a new pier was required to be constructed on reclamation land for a new storage facility. At this site, clay slurry dredged from the seabed has been used to form the top 3-4m of the soil deposit. The thickness of soft muddy clay below the reclaimed soil was approximately $5 \mathrm{~m}$, followed by a $7.5 \mathrm{~m}$ thick soft clay layer. A $6 \mathrm{~m}$ thick stiff silty clay lies underneath the soft clay layer. The groundwater level is located at the ground surface (Fig. 5). The undrained shear strength determined from the cone penetration tests varies from 15 to $35 \mathrm{kPa}$. The moisture content of the soil is generally close to or above the liquid limit. The void ratio is generally within the range of 0.8 1.5. A detailed description of the project has been reported elsewhere by Chu and Yan (2005).

As the undrained shear strength of the dredged soft soil is close to zero, the vacuum preloading method was selected to improve the soil characteristics. The required preloading pressure to attain the desired settlement with acceptable long-term settlement was $140 \mathrm{kPa}$. With an $80 \mathrm{kPa}$ vacuum pressure, an additional fill surcharge preloading was used to improve the shear strength of the soil. Among three embankment subsections, only Sections II and III will be analysed in this paper. The vertical cross-section and the locations of field 
instrumentation for Sections II and III are presented in Fig. 6, including the multi-level gauges, settlement gauges, piezometers and inclinometers. PVDs (100 mm $\times 3 \mathrm{~mm})$ with $20 \mathrm{~m}$ length were installed at $1 \mathrm{~m}$ spacing in a square pattern. A $0.3 \mathrm{~m}$ thick sand blanket was placed to serve as a platform for the PVD installation rig. It was required to place horizontal perforated pipes in the sand platform to apply and distribute vacuum pressure under the membrane system. The modified Cam-Clay parameters for all clay layers??are shown in Table 2.

\section{Three-dimensional finite element analysis}

As the aspect ratio of Section III footprint (width/length) was close to $1(15 / 25)$, a three dimensional (3D) finite element analysis was considered essential?? (Rujikiatkamjorn et al. 2008). A finite element software (ABAQUS v.6.7.1) was used to simulate the $3 \mathrm{D}$ multidrain analysis (SIMULIA, 2009). More than 90000 C3D8RP solid elements were used during the analysis (8-node tri-linear displacement and pore pressure) (Fig. 7). A total of 350 individual PVDs were represented and to simulate the vacuum boundary, the pore pressure was set along drain length to the amount of suction generated by the applied vacuum. A $150 \mathrm{~mm} \times 200 \mathrm{~mm}$ rectangular smear zone was simulated around the drain elements. This equivalent area of the rectangular smear zone equals to that of a circular $200 \mathrm{~mm}$ diameter smear zone (i.e. 2 times the equivalent diameter of the mandrel). The well resistance was neglected due to the very high discharge capacity of the drain, i.e. $q_{w}>120 \mathrm{~m}^{3} /$ year (Indraratna and Redana 2000).

\section{Two-dimensional finite element analysis}

The equivalent plane strain parameters determined from Equations (15)-(21) with vacuum application was adopted and the same section described earlier under 3D DEM was analysed under the plane strain condition. These 2D (plane strain) results will be used in 
comparison with 3D analyses. The 2D finite element mesh consisted of 14400 C2D8RP solid elements (8-node displacement and pore pressure) (Fig. 8). Considering the embankment symmetry, only one-half of the embankment was simulated. The vacuum pressure was specified by the negative pore pressure boundaries along the length of the drains.

\section{NUMERICAL RESULTS AND THEIR COMPARISON WITH FIELD DATA}

In this section, the predictions based on the equivalent 2D plane strain and 3D finite element analyses are compared with the field data including settlement, lateral displacement and excess pore pressure. Figure 9 shows a comparison between the predicted and measured field settlements at the embankment centreline with the loading sequence. As expected, the predicted settlements agree with the field data. The average volume of the extracted water per drain from the soil was $1.6 \mathrm{~m}^{3} /$ drain (3D analysis). This value depends not only on the discharge capacity of the drain, but also on the soil properties in the smear and undisturbed zones.

The comparison of predicted excess pore water pressure variation with time, at a depth of $5.5 \mathrm{~m}$ and $0.25 \mathrm{~m}$ away from the embankment centreline is illustrated in Fig. 10. The surcharge loading effect is shown by the increase in time-dependent pore pressure (indicated by arrows in Fig. 10). It can be seen that the reduction of pore pressures obtained from 2D analysis is more than that obtained from 3D FEM analysis during the initial two months. As expected, the pore pressure reduction becomes constant (-80 kPa) after about 120 days. Figure 11 illustrates the comparison between the measured and predicted lateral movements at the toe of the embankment after 5.5 months. The negative lateral displacement denotes an inward soil movement towards the centreline of the embankment. Again, the predictions from 2D and 3D agree well with the measured data. 
In general, the results obtained from the actual 3D and equivalent 2D approach based on the permeability conversion proposed by Indraratna et al. (2005a) are only slightly different to each other. In this method, the entire consolidation curve obtained from the equivalent $2 \mathrm{D}$ condition is almost the same as that of the $3 \mathrm{D}$ condition, thereby reducing the differences of pore pressure and lateral displacement predictions between the two analyses. In this context, this study shows that the equivalent plane strain analysis can be applied with confidence to obtain an acceptable accuracy, rather than having to always depend on a more cumbersome three-dimensional analysis.

\section{CONCLUSIONS}

A system of vertical drains combined with vacuum and surcharge preloading is an effective method for accelerating soil consolidation. In this study, an analytical model for consolidation via spectral method incorporating vacuum preloading as well as smear and well resistance was presented to consider the effect of the change in soil properties in a multi-layer soil. The versatility of the spectral model was demonstrated to accurately predict the soil behaviour subjected to vacuum pressure in both large-scale test and trial embankments at the Suvarnabhumi Airport. This case history analysis showed that the accurate prediction of complex vacuum assisted preloading can be captured to consider the actual multi-layer soil.

A 2D and 3D finite element code (ABAQUS) was employed to analyse the behaviour of a trial embankment subjected to vacuum preloading at Tianjin Port, China. A conversion procedure based on the transformation of permeability was introduced to compare the relative differences between the axisymmetric (3D) and equivalent plane strain (2D) conditions. The field behaviour as well as the model predictions indicate that the efficiency of vertical drains depends on the magnitude and distribution of vacuum pressure. In general, results obtained from the equivalent 2D approach were only slightly different to the $3 \mathrm{D}$ analysis, unless 
embankment aspect ratio approached unity. This shows that the equivalent plane strain analysis can be applied with confidence for acceptable accuracy, rather than having to always rely on a sophisticated and cumbersome three-dimensional analysis. To estimate the drain spacing, convenient design charts were developed in lieu of time-consuming trial and error methods. These design charts permit rapid manual calculations without the aid of a computer, and they are of great benefit to the practicing engineer.

\section{ACKNOWLEDGEMENT}

The authors wish to thank the Australian Research Council for its continuous support. A number of current and past research students of Prof. Indraratna, namely, Dr. R. Walker, Dr. I.W. Redana, Dr. C. Bamunawita and Dr. I Sathananthan have also contributed to the contents of this Keynote paper through their research work. Much of the contents reported in this paper are described in detail in a number of scholarly journals including Geotechnique, Canadian Geotechnical Journal and ASCE Journal of Geotechnical and Geoenvironmental Engineering, as cited in the text and listed below. The Authors also wish to thank Dr Jay Ameratunga for his technical suggestions and comments on this paper. Special appreciation is extended for the assistance of AIT staff (Prof. Dennes Bergado and Prof. Noppadol Phienwej) and for their insight into a number of field projects conducted in Thailand.

\section{APPENDIX A: DESIGN CHARTS FOR DETERMINING DRAIN SPACING}

Rujikiatkamjorn and Indraratna (2008) proposed design charts eliminating cumbersome iteration procedures using the equivalent drain diameter as an independent variable to obtain the relevant drain spacing. The design steps are summarised below: 
1. Use the available soil profiles, in-situ test measurements and laboratory data to obtain the relevant soil properties, hence, determine the appropriate installation depth $(l)$, and the desired consolidation time $(t)$;

2. Assume the required degree of consolidation $U_{t}$ for surcharge fill alone;

3. For vacuum pressure application, specify the mean suction, $p_{0}$, required total design stress $\Delta \sigma$, and the surcharge fill pressure, $\Delta p$ and then determine the required degree of consolidation from $U_{t, v a c}=\left(\Delta \sigma /\left(p_{0}+\Delta p\right)\right) * U_{t}$

4. Use $c_{v}, t$ and $l$, to determine $u^{*}$ using Fig. 12 or from,

$$
u^{*}=\sum_{m=1}^{\infty} \frac{8}{(2 m+1)^{2} \pi^{2}} \exp \left(-\left(\frac{2 m+1}{2}\right)^{2} \pi^{2} T_{v}\right)
$$

5. Determine the available size of the prefabricated vertical drains (circular or wick shape) and then compute the equivalent drain diameter (for wick drains), $d_{w}$ from $d_{w}=2(a+b) / \pi$;

6. Find $T_{h}^{\prime}$ from:

$T_{h}^{\prime}=c_{h} t / d_{w}^{2}$

7. Calculate $\gamma=-\frac{8 T_{h}^{\prime}}{\ln \left(\frac{1-U_{t}}{u^{*}}\right)}$ for surcharge fill only (no vacuum),

or $\gamma=-8 T_{h}^{\prime} / \ln \left(\frac{1-U_{t, v a c}}{u^{*}}\right)$ for vacuum pressure plus surcharge fill

8. Establish the diameter and permeability of the smear zone;

9. Determine $\xi$ using Fig. 13 or from the equation: 
$\xi=\left(\frac{k_{h}}{k_{s}}-1\right) \ln (s)$

10. Calculate $n$ from $n=\exp (\alpha \ln \gamma+\beta)$;

where, $\quad \alpha=0.3938-9.505 \times 10^{-4} \xi^{1.5}+0.03714 \xi^{0.5}$

and $\beta=0.4203+1.456 \times 10^{-3} \xi^{2}-0.5233 \xi^{0.5}$;

11. Calculate the influence zone $\left(d_{e}=n d_{w}\right)$;

12. Choose the drain pattern and determine the spacing of drain (d) from either $d=d_{e} / 1.05$ (triangular grid) or $d=d_{e} / 1.128$ (square grid).

\section{Worked-out Example}

The required soil parameters for the project are assumed to be: $U_{t}=90 \%, l=24 \mathrm{~m}, d_{w}=34$ mm (circular drain: Mebra-MCD34), $c_{h}=2.5 \mathrm{~m}^{2} /$ year, $c_{\mathrm{v}}=1.0 \mathrm{~m}^{2} /$ year, $k_{h} / k_{s}=5, s=3$, Maximum Design Surcharge, $\Delta \sigma=120 \mathrm{kPa}$, surcharge fill pressure, $\Delta p=60 \mathrm{kPa}$, vacuum pressure, $p_{0}=-60 \mathrm{kPa}$ (suction). Well resistance is neglected. Calculate the drain spacing $(d)$, for (a) $t=1.0$ year; (b) $t=9$ months; and (c) how the drain spacing can be altered with an increased vacuum pressure up to $90 \mathrm{kPa}$ over 9 months.

\section{Solution:}

Part (a) $t=1.0$ year

1. $T_{v}=1.0 \times 1 / 24^{2}=0.002 ; U_{t, v a c}=(120 /(60+60)) * 0.9=0.9$

2. Calculate $u^{*}$ using Equation 22 or from Fig. 12, hence, $u^{*}=0.95$

3. $T_{h}^{\prime}=c_{h} t / d_{w}^{2}=2.5 \times 1.0 / 0.034^{2}=2163$ 
4. $\gamma=-\frac{8 T_{h}^{\prime}}{\ln \left(\frac{1-U_{t, v a c}}{u^{*}}\right)}=-\frac{8 \times 2163}{\ln \left(\frac{1-0.9}{0.95}\right)}=7686$

5. From Fig. 13 or using Equation (26), $\xi=4.39$

6. Using Equations (28a \& 28b), determine $\alpha=0.463$ and $\beta=-0.649$.

7. From Equation (27), $n=\exp (\alpha \ln \gamma+\beta)=\exp (0.463 \times \ln 7686-0.649)=33$

8. Calculate $d_{e}$ from, $d_{e}=n d_{w}=33 \times 0.034=1.122 \mathrm{~m}$

9. Drain spacing $=1.1 \mathrm{~m}$ for triangular $(1.122 / 1.05)$ or $1.0 \mathrm{~m}$ for square grid $(1.122 / 1.128)$, respectively.

The above calculations confirm that the design spacing of $1 \mathrm{~m} \times 1 \mathrm{~m}$ used at Ballina Bypass. Australia can be justified for similar soil properties.

\section{Part (b) $t=0.75$ years $(9$ months)}

1. $T_{v}=1.0 \times 0.75 / 24^{2}=0.001 ; U_{t, v a c}=(120 /(60+60)) * 0.9=0.9$

2. Calculate $u^{*}$ using Equation 22 or from Fig. 12; hence, $u^{*}=0.96$

3. $T_{h}^{\prime}=c_{h} t / d_{w}^{2}=2.5 \times 0.75 / 0.034^{2}=1622$

4. $\gamma=-\frac{8 T_{h}^{\prime}}{\ln \left(\frac{1-U_{t, v a c}}{u^{*}}\right)}=-\frac{8 \times 1622}{\ln \left(\frac{1-0.9}{0.96}\right)}=5737$

5. Using Fig. 13 or from Equation (26), $\xi=4.39$

6. From Equations (28a and 28b), find $\alpha=0.463$ and $\beta=-0.649$.

7. From Equation (27), $n=\exp (\alpha \ln \gamma+\beta)=\exp (0.463 \times \ln 5737-0.649)=29$ 
8. Calculate $d_{e}$ from $d_{e}=n d_{w}=29 \times 0.034=0.986 \mathrm{~m}$

9. Drain spacing $=0.95 \mathrm{~m}$ for triangular grid (i.e. $0.986 / 1.05$ ) or $0.90 \mathrm{~m}$ for square grid (i.e. 0.986/1.128).

Part (c): Vacuum pressure increased up to 90 kPa over 9 months. Revised Drain Spacing?

1. $T_{v}=1 \times 0.75 / 24^{2}=0.001 ; U_{t, v a c}=(120 /(90+60)) * 0.9=0.72$

2. Calculate $u^{*}$ using Equation 22 or Fig. 12, Hence, $u^{*}=0.96$

3. $T_{h}^{\prime}=c_{h} t / d_{w}^{2}=2.5 \times 0.75 / 0.034^{2}=1622$

4. $\gamma=-\frac{8 T_{h}^{\prime}}{\ln \left(\frac{1-U_{t, v a c}}{u^{*}}\right)}=-\frac{8 \times 1622}{\ln \left(\frac{1-0.72}{0.96}\right)}=10531$

5. Use Fig. 13 or Equation (26), $\xi=4.39$

6. Using Equations (28a and 28b), find $\alpha=0.463$ and $\beta=-0.649$.

7. From Equation (27), $n=\exp (\alpha \ln \gamma+\beta)=\exp (0.463 \times \ln 10531-0.649)=38$

8. Calculate $d_{e}$ from $d_{e}=n d_{w}=38 \times 0.034=1.29 \mathrm{~m}$

9. Drain spacing $=1.23 \mathrm{~m}$ for triangular pattern (i.e. $1.29 / 1.05$ ) or $1.14 \mathrm{~m}$ for square grid (i.e.1.29/1.128).

This demonstrates that increased vacuum pressure allows the drain spacing to be increased. This should also reduce the risk of smear overlapping and achieve reduced drain costs. 


\section{REFERENCES}

Bergado, D.T, Chai, J.C, and Balasubramaniam, A.S (1998). PVD improvement of soft Bangkok clay using combined vacuum and reduced sand embankment preloading, Geotechnical Engineering Journal, 29 (1) 95-122.

Bergado, D.T., Balasubramanian, A.S., Fannin, R.J., Holtz, R.D., (2002). Prefabricated vertical drain (PVD) in soft Bangkok clay: a case of NBIA Project. Canadian Geotechnical Journal 39 (2), 304-315.

Chai, J. C., Shen, S. L., Miura, N. and Bergado, D. T. (2001) Simple method of modeling PVD improved subsoil. Journal of Geotechnical and Geoenvironmental Engineering, ASCE, 127 (11) 965-972.

Chai, J. C., Hong, Z.-S., and Shen, S.-L. (2010). Vacuum-drain method induced pressure distribution and ground deformation, Geotextiles and Geomemberanes, 28, pp. 525535.

Chu, J., and Yan, S.W. (2005). Application of vacuum preloading method in soil improvement. Ground Improvement-Case Histories, Indraratna, B. \& Chu, J. (Eds.), Elsevier, 91-118.

Chu, J. Yan, S.W. and Zheng, Y.R. (2006). Three soil improvement methods and their applications to road construction. Ground Improvement, 10 (3), 103- 112.

Chu, J., Yan, S.W. and Yang, H. (2000), Soil improvement by the vacuum preloading method for an oil storage station, Geotechnique 50 (6) pp. 625-632.

Hansbo, S. (1981). Consolidation of fine-grained soils by prefabricated drains and lime column installation. Proceedings of 10th International Conference on Soil Mechanics and Foundation Engineering, Balkema (Rotterdam) 3: 677-682.

Hird, C. C., Pyrah, I. C., and Russell, D. (1992). Finite element modelling of vertical drains beneath embankments on soft ground. Geotechnique, London, 42(3), 499-511. 
Indraratna, B., and Redana, I.W. (2000). Numerical modeling of vertical drains with smear and well resistance installed in soft clay. Canadian Geotechnical Journal, 37: 133145.

Indraratna, B., Bamunawita, C. and Khabbaz, H (2004). Numerical Modelling of Vacuum Preloading \& Field Applications, Canadian Geotechnical Journal, Vol. 41, pp. 10981110.

Indraratna, B., Rujikiatkamjorn C., and Sathananthan, I. (2005a). Analytical and numerical solutions for a single vertical drain including the effects of vacuum preloading. Canadian Geotechinical Journal, 42, 994-1014.

Indraratna, B., Rujikiatkamjorn C., Balasubramaniam, A. S. and Wijeyakulasuriya, V. (2005b). Predictions and observations of soft clay foundations stabilized with geosynthetic drains and vacuum surcharge. Ground Improvement - Case Histories Book (Volume 3), Edited by Indraratna, B. and Chu, J., Elsevier, London, pp. 199230.

Leong E.C., Soemitro R., and Rahardjo H. (2000). Soil Improvement by surcharge and vacuum preloading, Geotechnique 50(5): 601 - 605.

Mohamedelhassan, E., and Shang, J.Q. (2002). Vacuum and surcharge combined onedimensional consolidation of clay soils. Can. Geotech. J. 39, 1126-1138.

Rujikiatkamjorn C. and Indraratna, B. (2009). Design procedure for vertical drains considering a linear variation of lateral permeability within the smear zone. Canadian Geotechnical Journal 46(3), 270-280.

Rujikiatkamjorn C., Indraratna, B. and Chu, J. (2008). 2D and 3D Numerical Modeling of Combined Surcharge and Vacuum Preloading with Vertical Drains. International Journal of Geomechanics, ASCE, 8(2), 144-156.

SIMULIA (2009). ABAQUS/Standard User's Manual, Published by HKS Inc. 
Saowapakpiboon, J., Bergado, D.T., Youwai, S., Chai, J.C., Wanthong, P. and Voottipruex, P. (2010). Measured and predicted performance of prefabricated vertical drains (PVDs) with and without vacuum preloading, Geotextile and Geomembranes, 28(1), 1-11.

Seah, T.H. (2006). Design and construction of ground improvement works at Suvarnabhumi Airport. Geot. Eng, J. of Southeast Asian Geot. Society, 37, 171-188.

Shang, J.Q., Tang, M., and Miao, Z. (1998). Vacuum preloading consolidation of reclaimed land: a case study. Canadian Geotechnical Journal, 35, 740-749.

Tran, T.A. and Mitachi, T. (2008). Equivalent plane strain modeling of vertical drains in soft ground under embankment combined with vacuum preloading. Computers and Geotechnics 35(5): 655-672.

Walker, R. (2006). Analytical solutions for modeling soft soilconsolidation by vertical drains. $\mathrm{PhD}$ thesis, University of Wollongong, NSW, Australia.

Walker, R. and Indraratna, B. (2006). Vertical Drain Consolidation with Parabolic Distribution of Permeability in Smear Zone. J. of Geotechnical \& Geoenvironmental Engineering, ASCE, Vol. 132(7), 937-941.

Walker, R. and Indraratna, B. (2007). Vertical drain consolidation with overlapping smear zones. Geotechnique, Institution of Civil Engineers, UK, 57(5). pp. 463-467.

Walker, R. and Indraratna, B. (2009). Consolidation analysis of a stratified soil with vertical and horizontal drainage using the spectral method, Géotechnique, 59(1), 1-11. 


\section{List of Tables}

Table 1 Soil parameters for the test embankments (After Walker and Indraratna 2009)

Table 2 Soil parameters in 2D and 3D FEM analysis (After Rujikiatkamjorn et al. 2008)

\section{List of Figures}

Fig. 1. Unit cell

Fig. 2. Permeability distribution in smear zone (a) constant (b) linear and (c) parabolic

Fig. 3. Soil profile at the Suvarnabhumi Airport (After Indraratna et al. 2005b)

Fig. 4. Measured and predicted settlement at Suvarnabhumi Airport (After Walker 2006)

Fig.5. Soil profiles at Tianjin Port (After Chu and Yan 2005)

Fig. 6. Embankment plan view with field instrumentation(After Chu and Yan 2005)

Fig. 7. 3D finite element mesh discretisation

Fig. 8. 2D finite element mesh discretisation

Fig. 9. (a) Loading history and (b) Consolidation settlements

Fig. 10 Pore pressure variation at $0.25 \mathrm{~m}$ away from the embankment centerline at $5.5 \mathrm{~m}$ depth (arrows indicate times when surcharge loads were applied)

Fig. 11 Lateral displacements at embankment toe at 180th day

Fig. 12. Relationship between Tv and u* (Rujikiatkamjorn and Indraratna 2009)

Fig. 13. Contour plot of $\xi$ based on Equation (19) (Rujikiatkamjorn and Indraratna 2009) 
Table 1 Soil parameters for the test embankments (After Walker and Indraratna 2009)

\begin{tabular}{llllllllllll}
\hline $\begin{array}{l}\text { Depth } \\
(\mathrm{m})\end{array}$ & $\lambda$ & $\kappa$ & $v$ & & $e_{0}$ & $\begin{array}{l}\gamma \\
\left(\mathrm{kN} / \mathrm{m}^{3}\right)\end{array}$ & $\begin{array}{l}\left.{ }^{9} \mathrm{~m} / \mathrm{s}\right) \\
\left(10^{-}\right.\end{array}$ & $\left.\begin{array}{l}k_{h} \\
\left(10^{-}\right.\end{array} / \mathrm{s}\right)$ & $k_{v} / \bar{k}_{v}$ & $\eta / \bar{\eta}$ & $m_{v} / \bar{m}_{v}$ \\
\hline $0-2$ & 0.3 & 0.03 & 0.3 & 2.3 & 1.8 & 16 & 15.1 & 30.1 & 2.36 & 2.36 & 0.37 \\
$2-8.5$ & 0.7 & 0.08 & 0.3 & 5.1 & 2.8 & 15 & 6.4 & 12.7 & 1.00 & 1.00 & 1.00 \\
$\begin{array}{l}8.5- \\
10.5\end{array}$ & 0.5 & 0.05 & 0.25 & 4.4 & 2.4 & 15 & 3.0 & 6.0 & 0.47 & 0.47 & 0.34 \\
$10.5-$ & & & & & & & & & & & \\
13 & 0.3 & 0.03 & 0.25 & 3.0 & 1.8 & 16 & 1.3 & 2.6 & 0.20 & 0.20 & 0.25 \\
$13-15$ & 0.1 & 0.01 & 0.25 & 1.6 & 1.2 & 18 & 0.3 & 0.6 & 0.05 & 0.05 & 0.09 \\
\hline
\end{tabular}


Table 2. Soil parameters in 2D and 3D FEM analysis (After Rujikiatkamjorn et al. 2008)

\begin{tabular}{cccccccccccc}
\hline $\begin{array}{c}\text { Depth } \\
(\mathrm{m})\end{array}$ & $\lambda$ & $\kappa$ & $v$ & & $e_{0}$ & $\begin{array}{c}\gamma \\
\mathrm{kN} / \mathrm{m}^{3}\end{array}$ & $\begin{array}{c}k_{v} \\
10^{-10} \\
\mathrm{~m} / \mathrm{s}\end{array}$ & $\begin{array}{c}k_{h, a x} \\
10^{-10} \\
\mathrm{~m} / \mathrm{s}\end{array}$ & $\begin{array}{c}k_{s, a x} \\
10^{-10} \\
\mathrm{~m} / \mathrm{s}\end{array}$ & $\begin{array}{c}k_{h, p s} \\
10^{-10} \\
\mathrm{~m} / \mathrm{s}\end{array}$ & $\begin{array}{c}k_{s, p s} \\
10^{-10} \\
\mathrm{~m} / \mathrm{s}\end{array}$ \\
\hline $0.0-3.5$ & 0.12 & 0.03 & 0.3 & 1.4 & 1.1 & 18.3 & 6.67 & 20 & 6.67 & 5.91 & 1.46 \\
$3.5-8.5$ & 0.14 & 0.03 & 0.25 & 1.6 & 1.0 & 18.8 & 13.3 & 40 & 13.3 & 11.8 & 2.92 \\
$8.5-16.0$ & 0.20 & 0.04 & 0.3 & 2.3 & 1.4 & 17.5 & 6.67 & 20 & 6.67 & 5.91 & 1.46 \\
$16.0-20.0$ & 0.10 & 0.02 & 0.27 & 1.4 & 0.9 & 18.5 & 1.67 & 5 & 1.67 & 1.48 & 0.365 \\
\hline
\end{tabular}

Note: $\kappa \quad$ Slope of consolidation curve for unloading stage

$\lambda \quad$ Slope of consolidation curve for loading stage after preconsolidation pressure

$v \quad$ Poisson's ratio in terms of effective stress at in-situ effective stress

$\gamma_{\mathrm{w}} \quad$ Unit weight of soil

OCR Overconsolidation ratio 


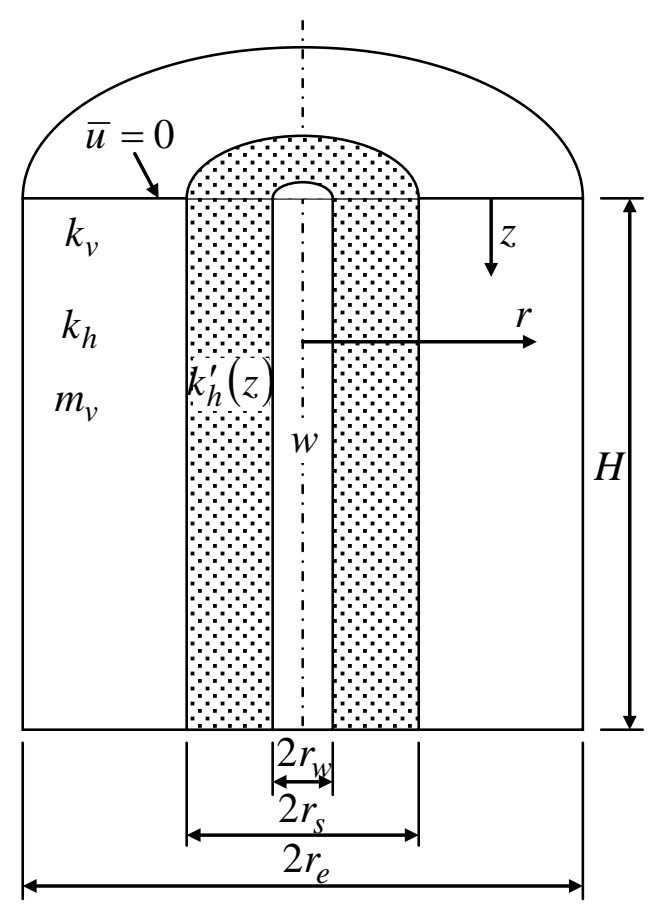

Fig. 1. Unit cell 


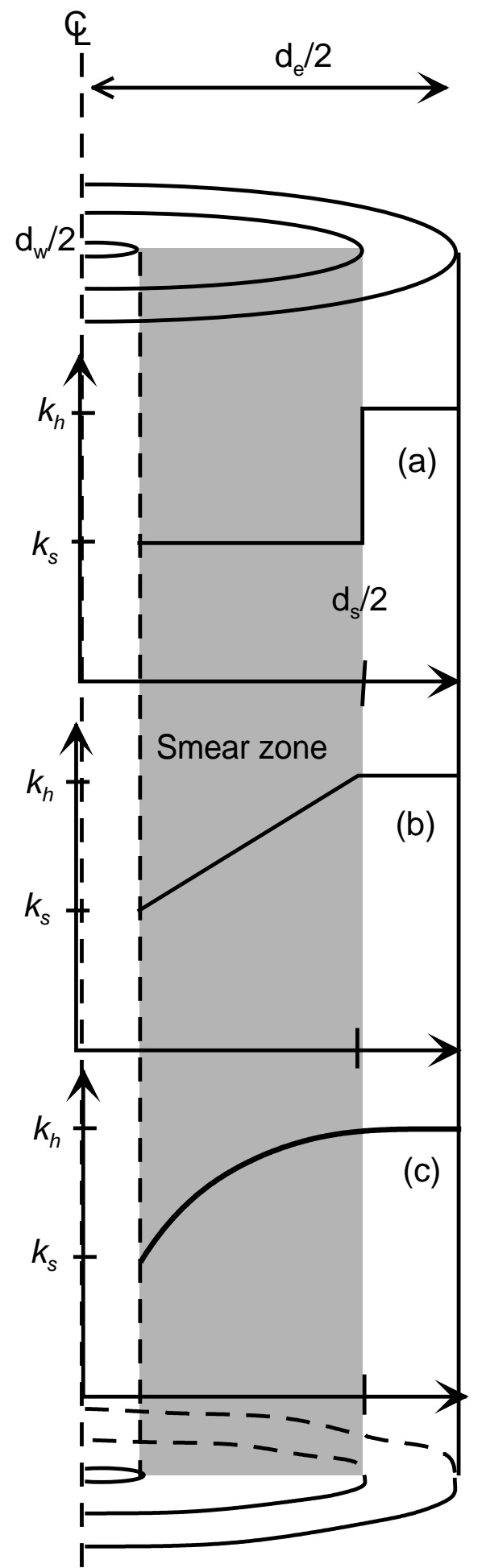

Fig. 2. Permeability distribution in smear zone (a) constant (b) linear and (c) parabolic 


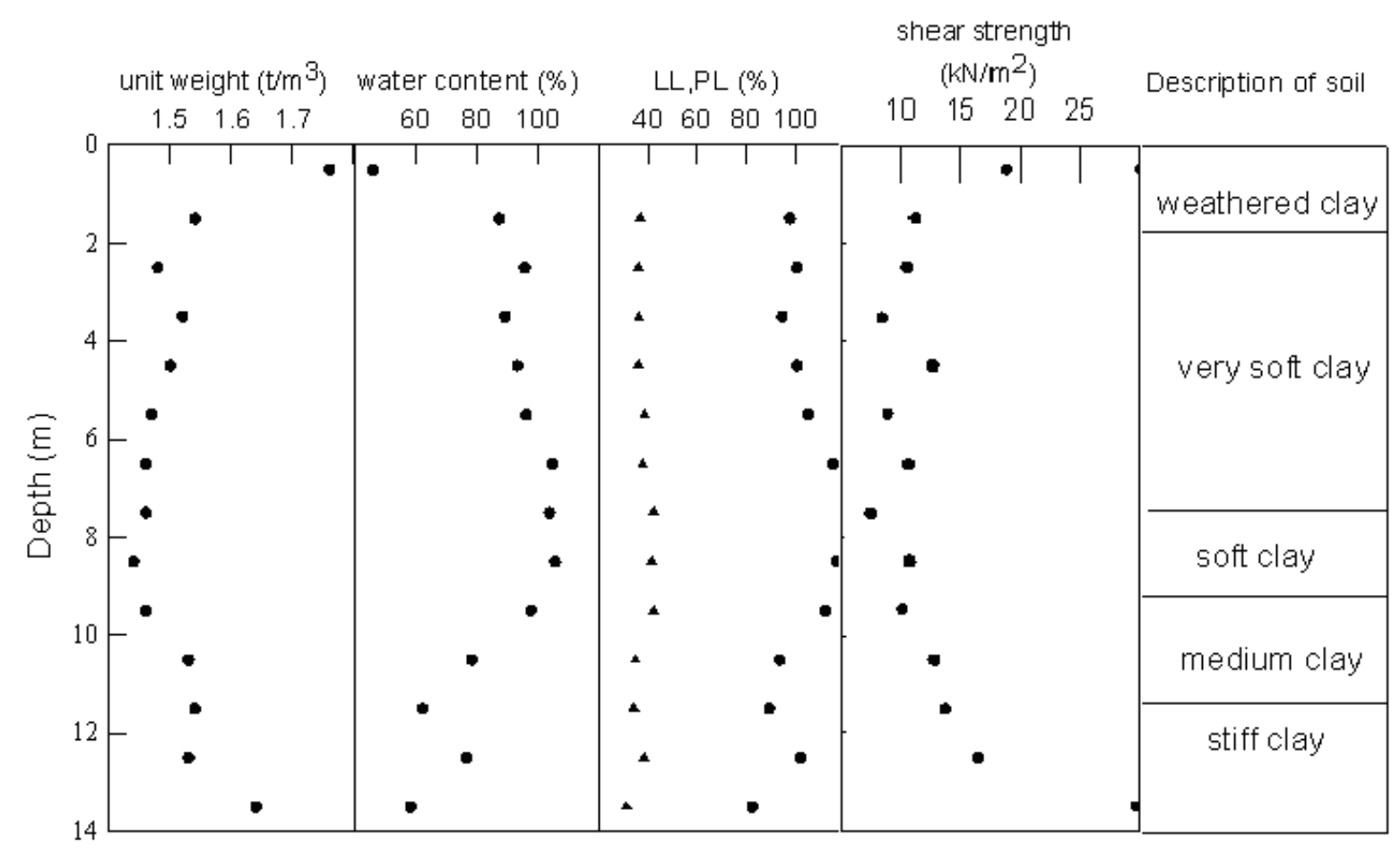

Fig. 3. Soil profile at the Suvarnabhumi Airport (After Indraratna et al. 2005b) 


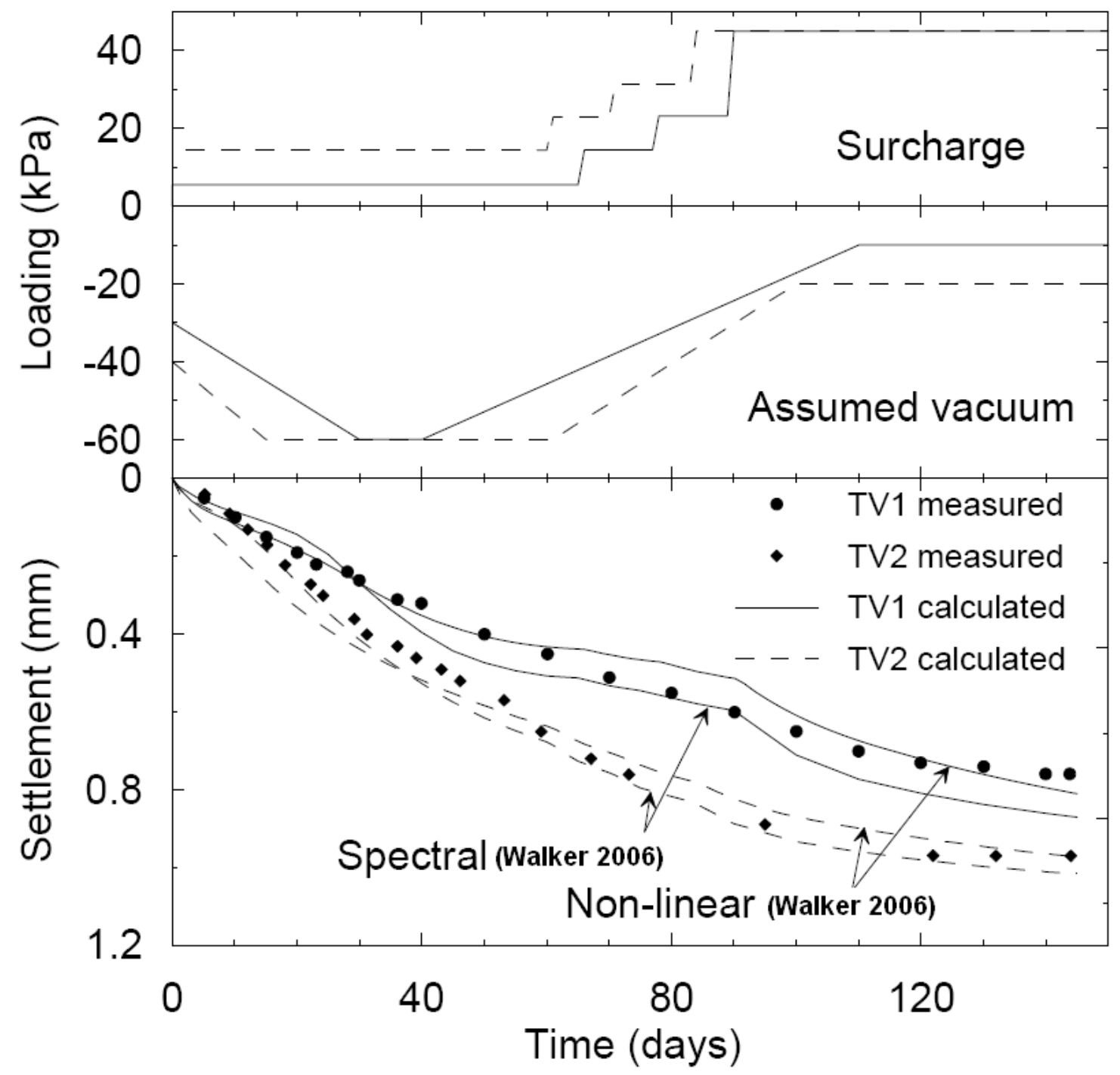

Fig. 4. Measured and predicted settlement at Suvarnabhumi Airport (After Walker 2006) 


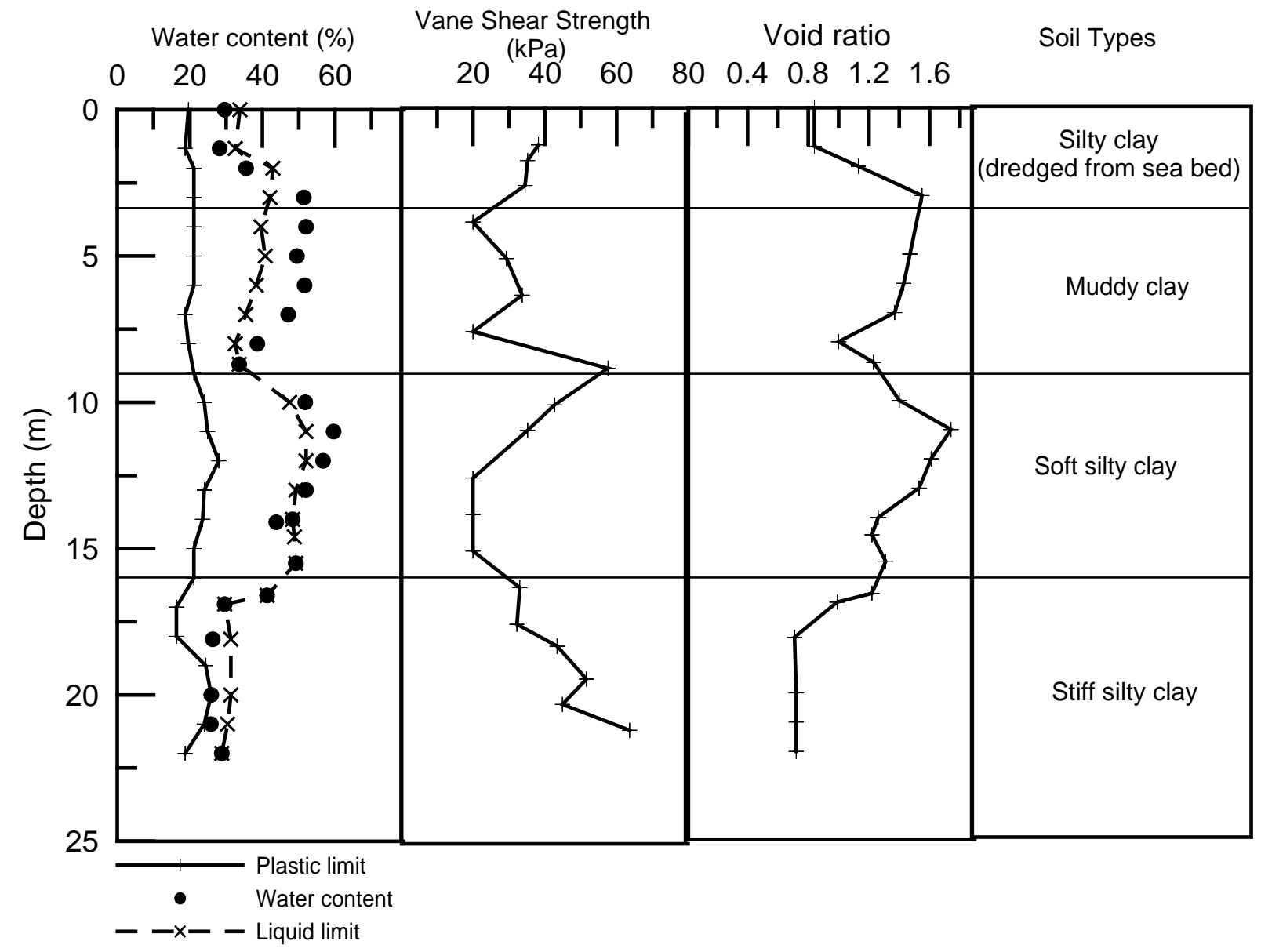

Fig.5. Soil profiles at Tianjin Port (After Chu and Yan 2005) 


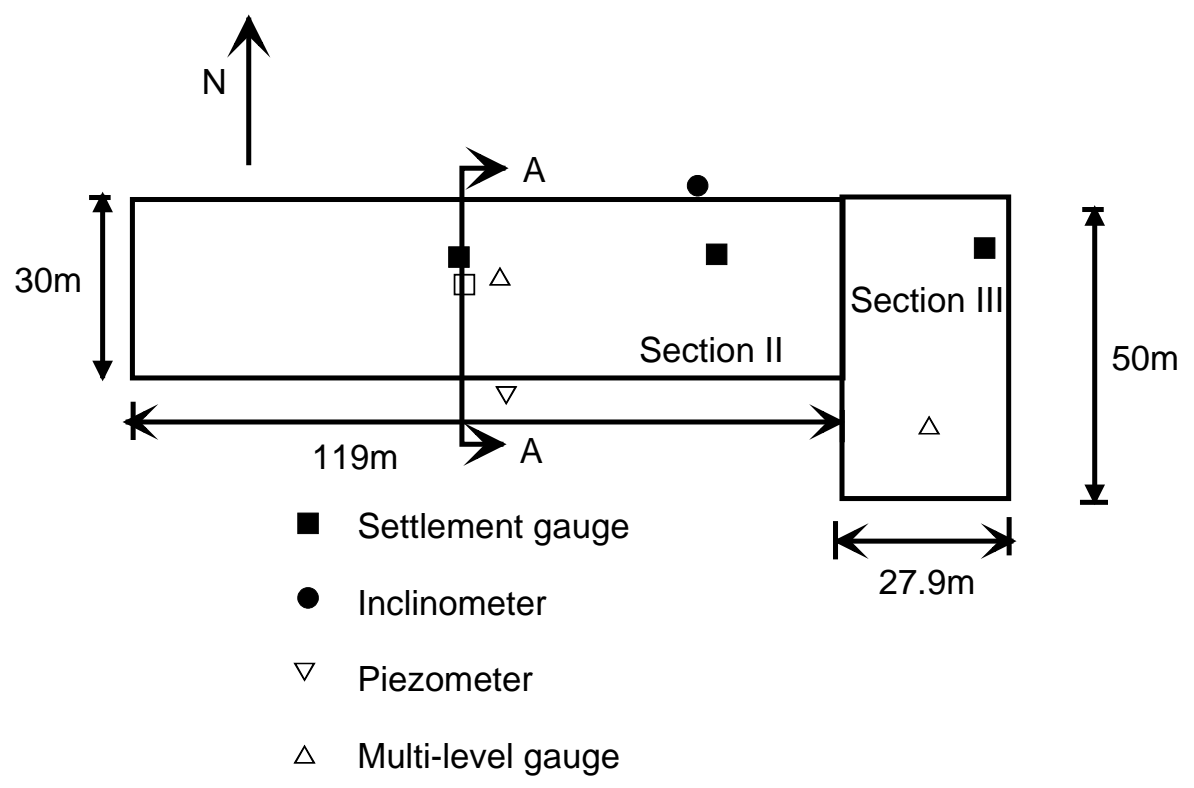

Fig. 6. Embankment plan view with field instrumentation(After Chu and Yan 2005) 


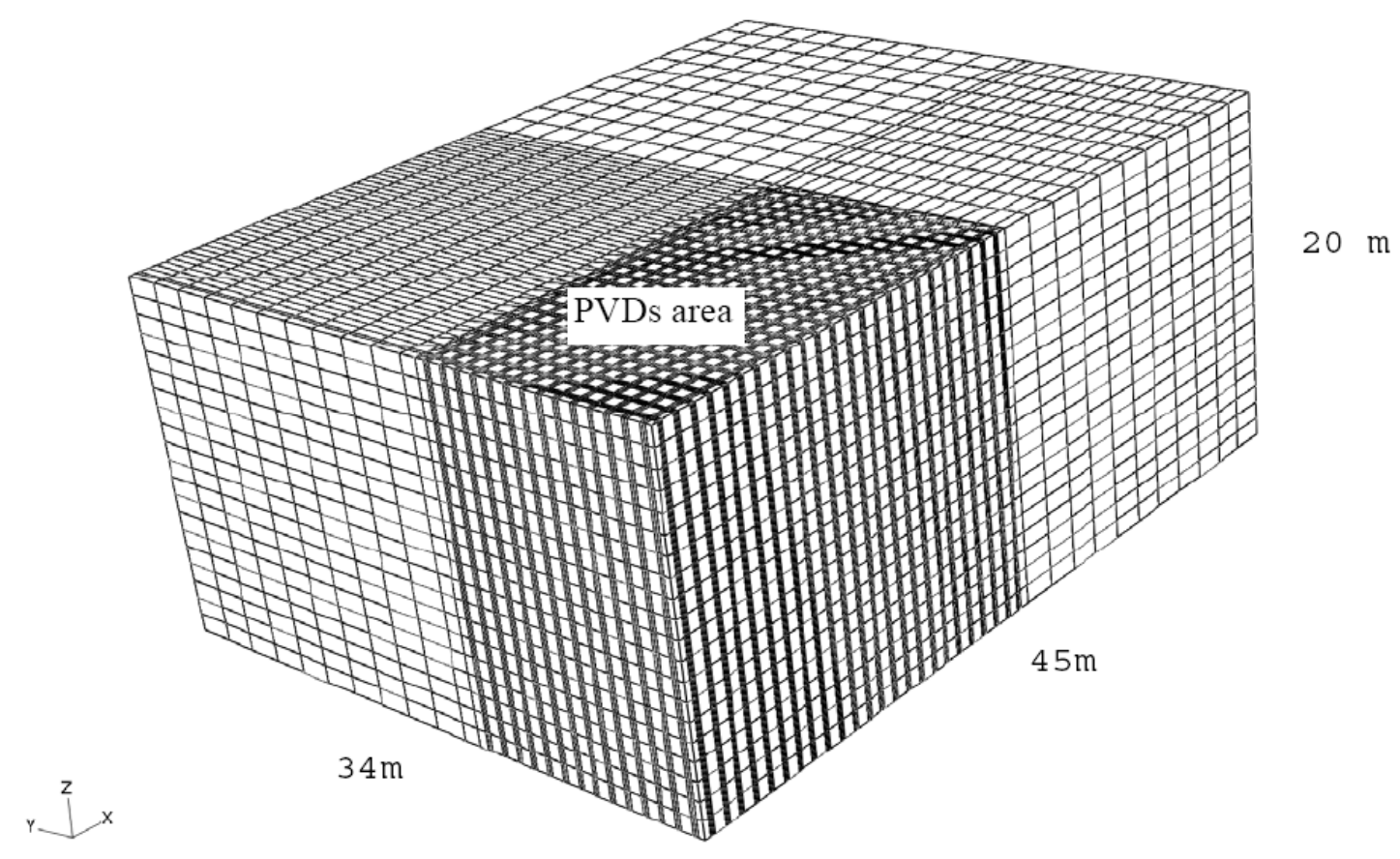

Fig. 7. 3D finite element mesh discretisation 


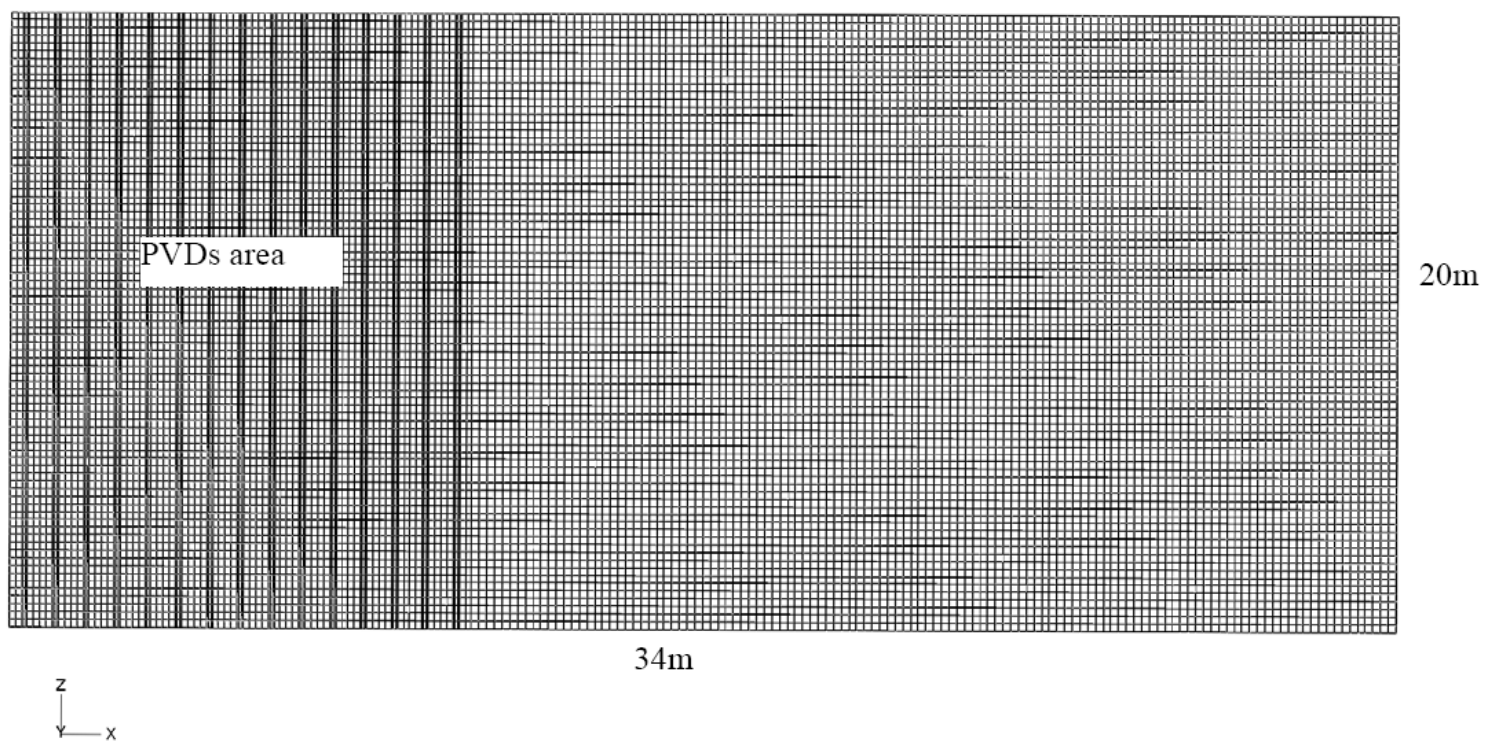

Fig. 8. 2D finite element mesh discretisation 


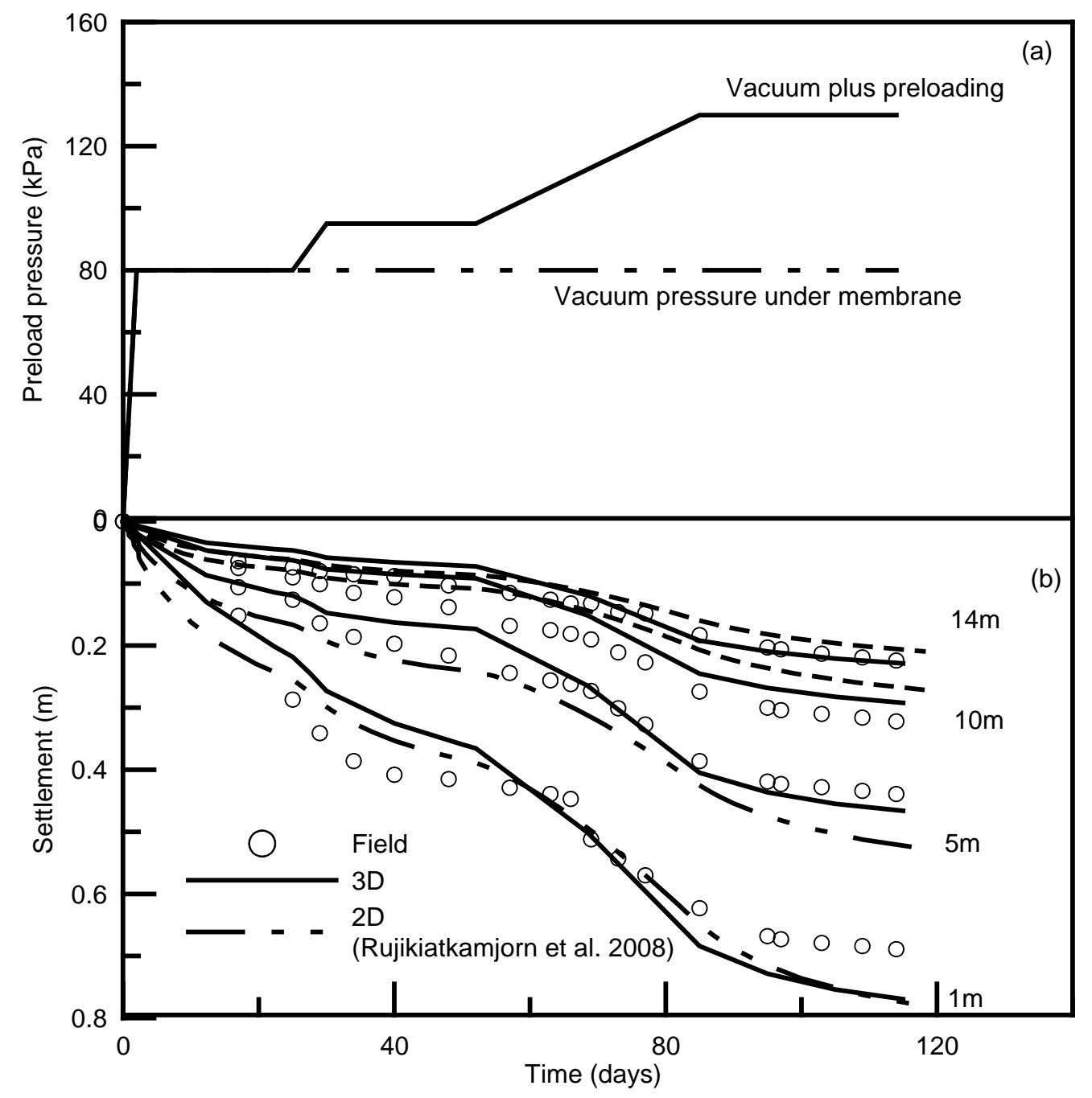

Fig.9. (a) Loading history and (b) Consolidation settlements 


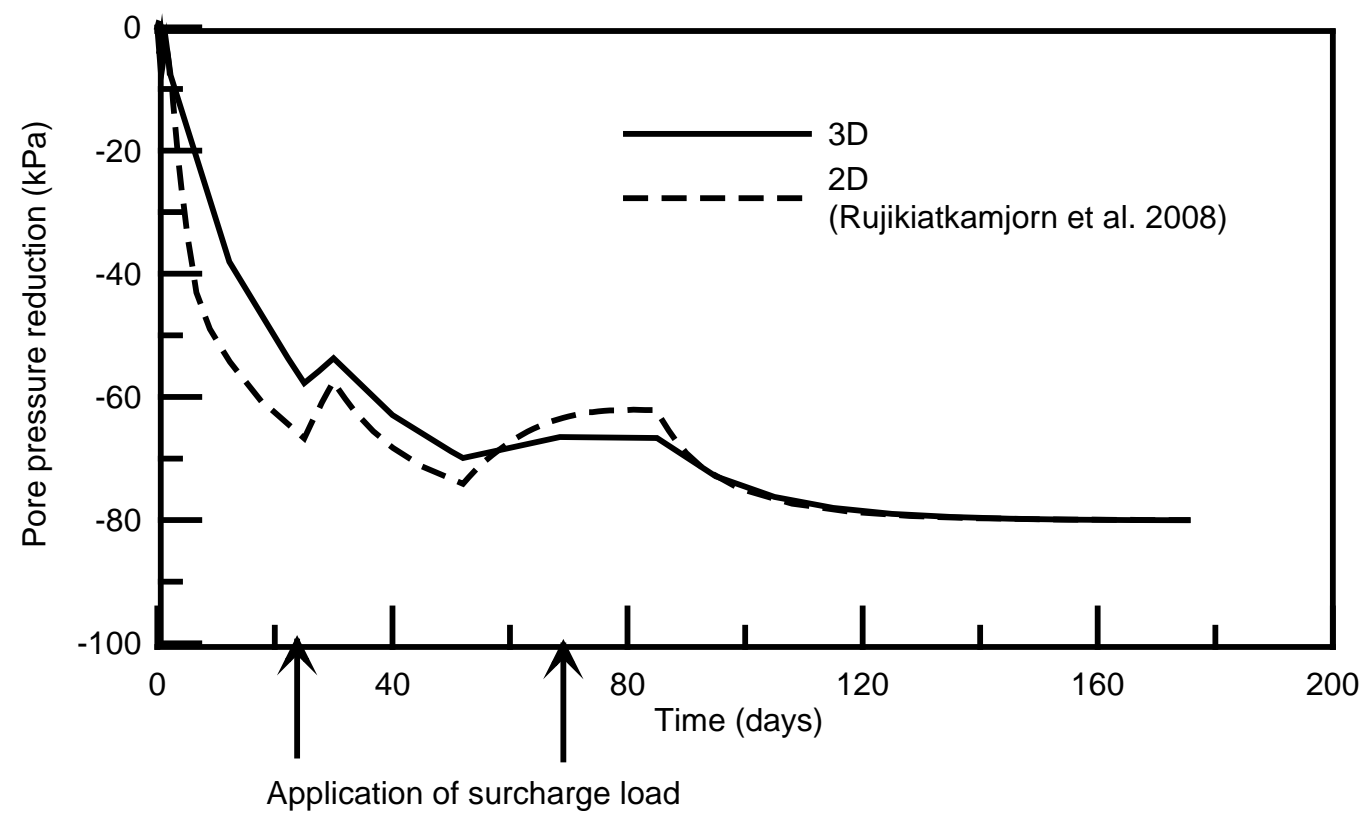

Fig. 10 Pore pressure variation (Section III) at $0.25 \mathrm{~m}$ away from the embankment centerline at 5.5m depth (arrows indicate times when surcharge loads were applied) 


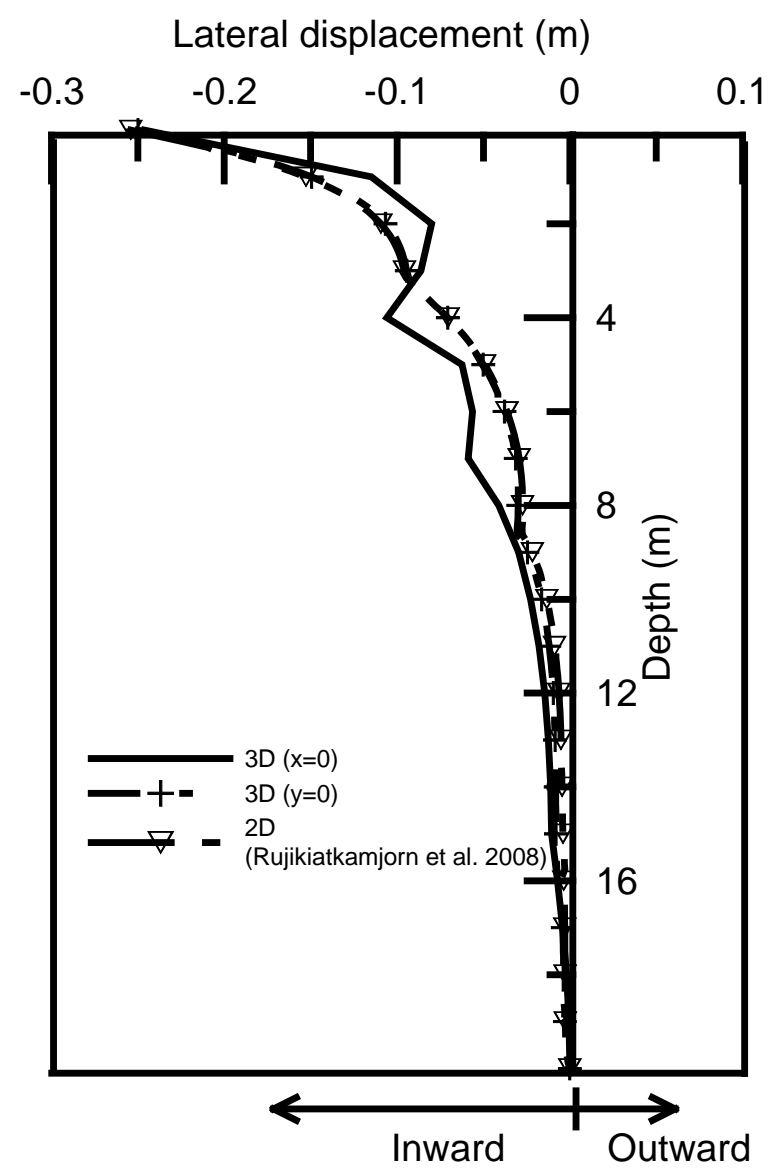

Fig. 11 Lateral displacements at embankment toe at $180^{\text {th }}$ day 


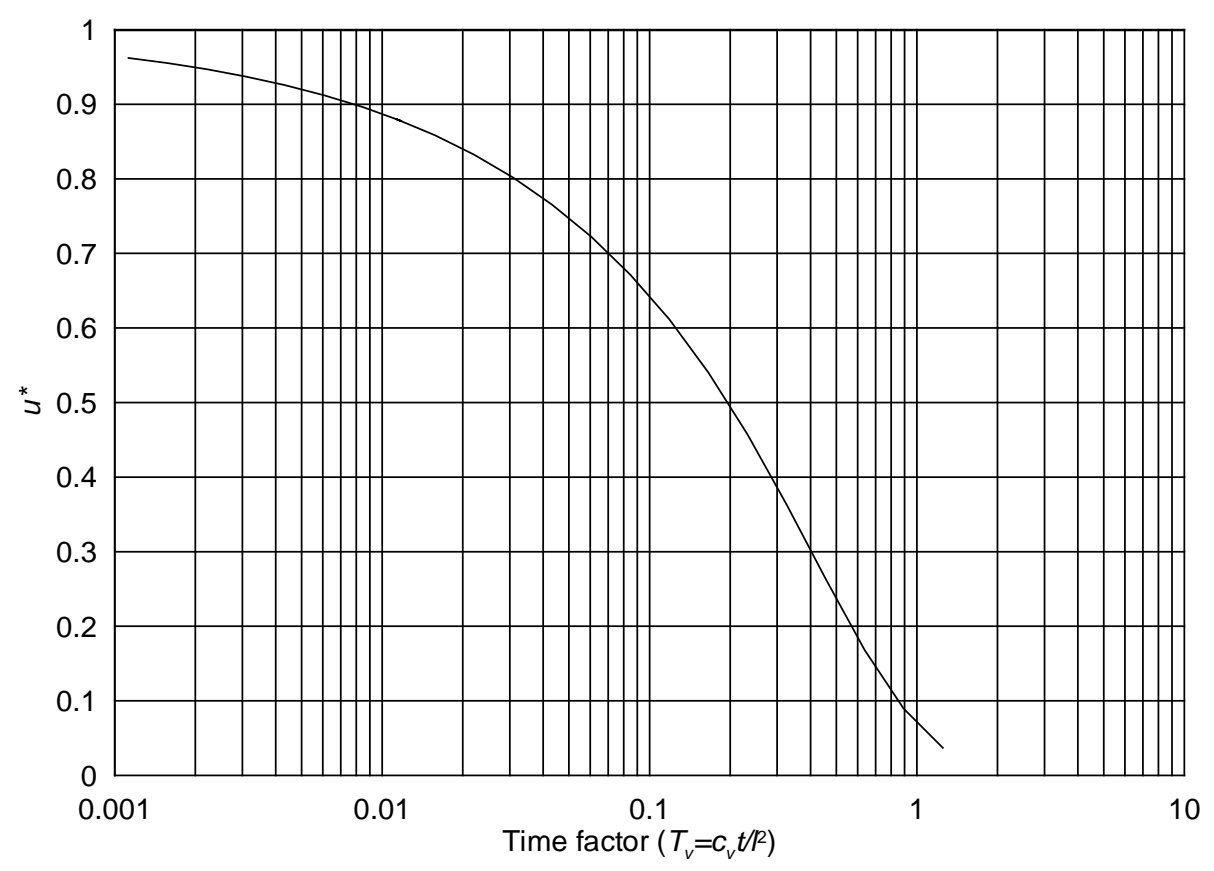

Fig. 12. Relationship between $T_{v}$ and $u^{*}$ (Rujikiatkamjorn and Indraratna 2009)

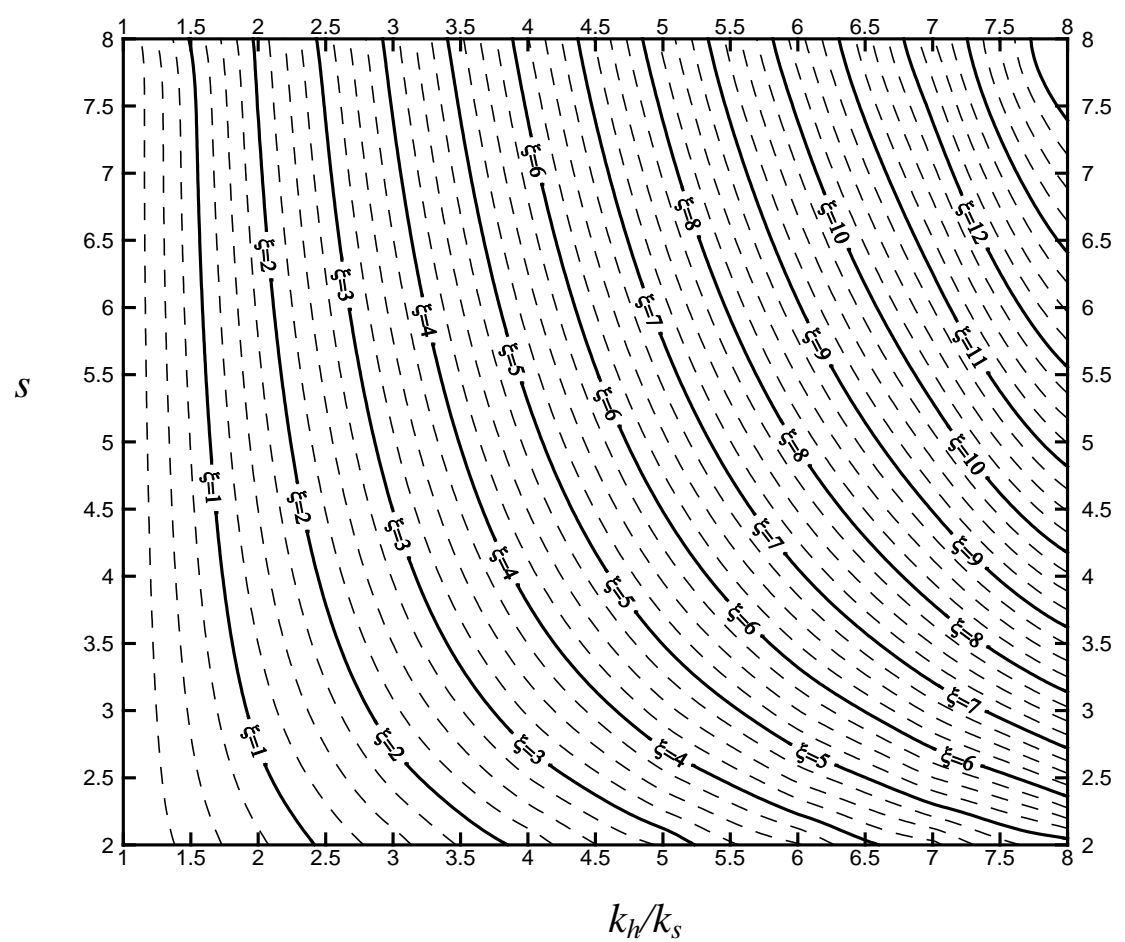

Fig. 13. Contour plot of $\xi$ based on Equation (19) (Rujikiatkamjorn and Indraratna 2009) 